\title{
Chemical alteration of sediments on early stage of existing of hydrothermal systems in spreading zones of sedimented ridges (hydrothermal field "Dead Dog", Middle Valley, Juan de Fuca Ridge)
}

\author{
Alexandra Khakhina ${ }^{1}$, Victor Kurnosov ${ }^{1}$, Yurii Konovalov ${ }^{1}$, Valeriya Churkina $^{1, *}$, and \\ Konstantin Galin ${ }^{1}$ \\ ${ }^{1}$ Geological Institute, 119017 Moscow, Russia
}

\begin{abstract}
In sediments from Holes DSDP 858B, D, F, located near the active hot vent on the thermal field "Dead Dog" in the northern part of the Juan de Fuca Ridge, Middle Valley, a redistribution of chemical elements occurs as a result of solution-rock interaction. During this process, the increase/decrease of their content in hydrothermally altered sediments inversely reflects the decrease/increase of their content in the solution. Nonregular distribution of microelements and REE's in hydrothermally altered sediments, like a layer pie, reflects the participation of both ascending hydrothermal fluids and lateral flows of hydrothermal solutions in alteration of chemical composition of sediments.
\end{abstract}

\section{Introduction}

Middle Valley of the Juan de Fuca Ridge represents a model of oceanic crust formation by the rifting of continental margins [1,2], when thick masses of sediments deposit in spreading rifts with a high rate of speed $(1200-2300 \mathrm{~m} / \mathrm{mln}$.y) and covers spreading zones with hydrothermal systems. Holes 858A, B, C, D, F were drilled in the northern part of Juan de Fuca Ridge (Middle Valley), on the hydrothermal field "Dead Dog", during Leg 139 ODP. They were located in a modern hydrothermal system covered with Holocene and Upper Pleistocene turbidites interbedded with hemipelagic sediments [1]. Hydrothermal field "Dead Dog" is an appropriate site for studying hydrothermally altered sediments, overlying a spreading zone in axis zones of mid-ocean ridges are located near the continents. Except this, only one similar site with deep-sear holes drilled is known. It is Central Hill in Escanaba Trough, Gorda Ridge, Pacific Ocean [3].

\footnotetext{
*Corresponding author: lera.keily@gmail.com
} 


\section{Objects and methods}

Middle Valley of the Juan de Fuca Ridge (Fig. 1) is a tectonomagmatic structure of medium-rate spreading $(58 \mathrm{~mm} /$ year) $[1,2]$, in which the "Dead Dog" hydrothermal field with high heat flow $\left(4-20 \mathrm{~W} / \mathrm{m}^{2}\right)$ and hot springs with temperatures ranging from 234 to $276^{\circ} \mathrm{C}$ is located. Several holes were drilled in the hydrothermal field at an ocean depth of 2409-2416 m (Fig. 2). Hole 858B was drilled to a depth of $38.6 \mathrm{~m}$ near the hydrothermal spring with a temperature of $276^{\circ} \mathrm{C}$. At a depth of $19.5 \mathrm{~m}$, the temperature in this hole is $197^{\circ} \mathrm{C}$. Holes $858 \mathrm{D}, \mathrm{F}$ are located the same as Hole $858 \mathrm{~B}$, near hot springs. In Hole 858D (depth $40.7 \mathrm{~m}$ ), the temperature at a depth of $18.8 \mathrm{~m}$ is $208^{\circ} \mathrm{C}$. Hole $858 \mathrm{~F}$ was drilled to a depth of $250 \mathrm{~m}$. Hole $858 \mathrm{C}$ (depth $93.1 \mathrm{~m}$ ) is located $75 \mathrm{~m}$ from the hydrothermal spring with a temperature of $268^{\circ} \mathrm{C}$. The temperature gradient in it is $3^{\circ} \mathrm{C} / \mathrm{m}$. Hole $858 \mathrm{~A}$ is located $150 \mathrm{~m}$ from the hot spring. Its depth is $339 \mathrm{~m}$, the temperature gradient is $1.7^{\circ} \mathrm{C} / \mathrm{m}$. Holes $858 \mathrm{~B}, \mathrm{D}, \mathrm{F}$ that were drilled near hot springs in the zones of upflow of hydrothermal fluids were selected for the study.

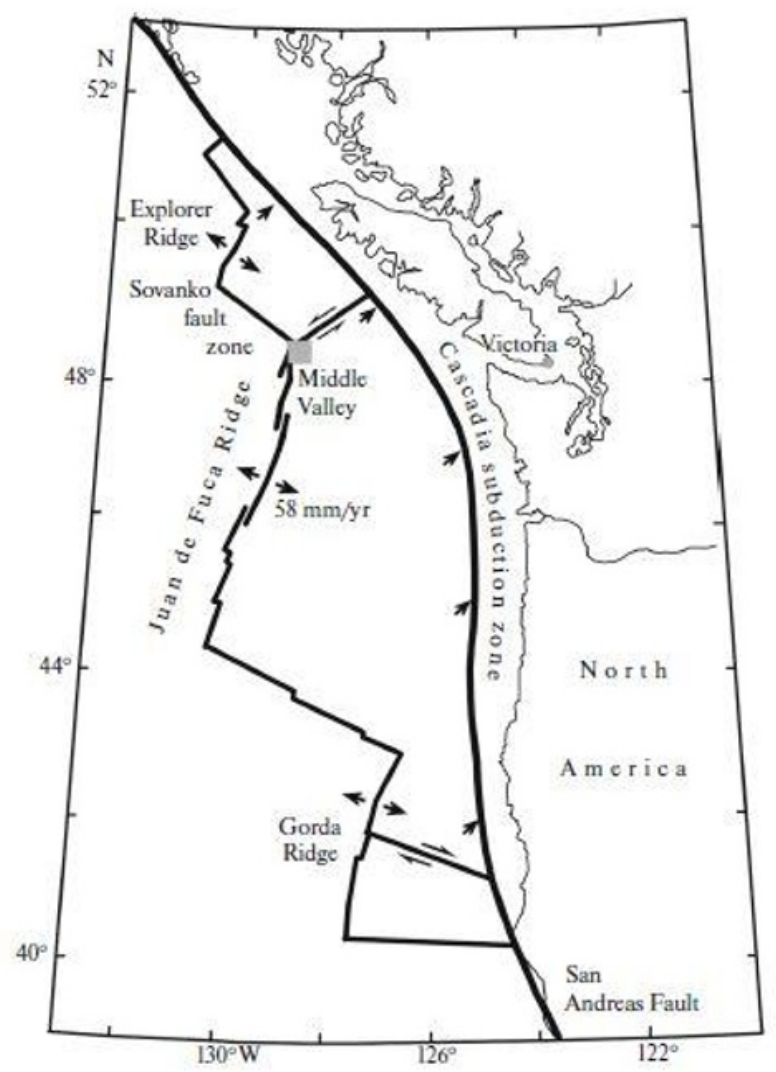

Fig. 1. The structural-tectonic scheme of the location of the Middle Valley of the Juan de Fuca Ridge; the arrows indicate plate motion, from [1]. 


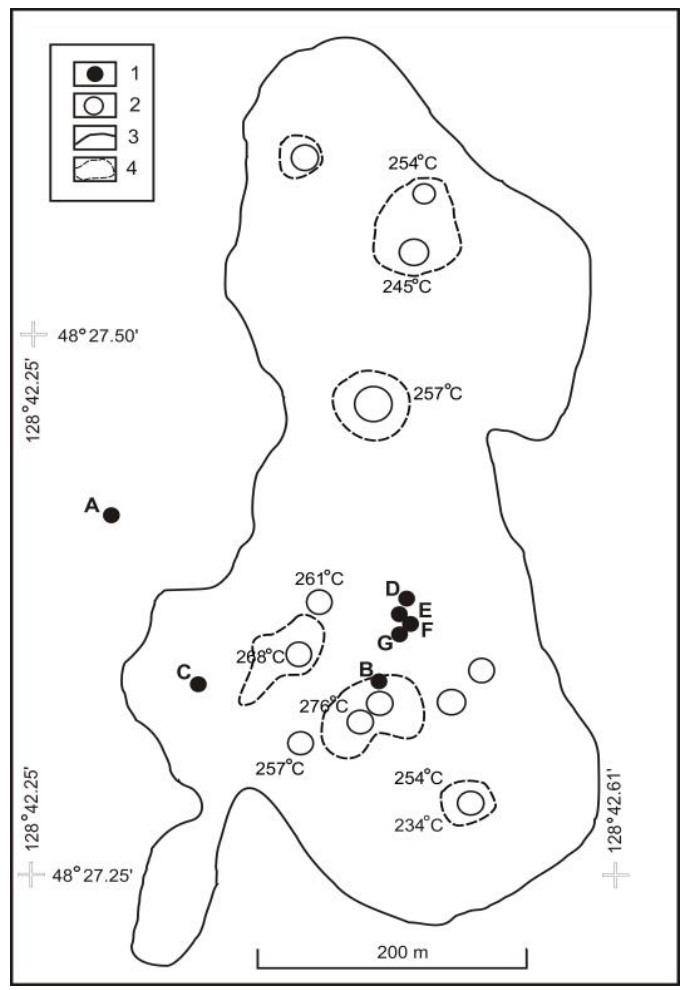

Fig. 2. Location of ODP Holes and hydrothermal vents in the Dead Dog hydrothermal field [1]. (1) ODP Holes; (2) hydrothermal vents; (3) acoustic edge hydrothermal field; (4) isobates.

Holes 855A, C, D are located at the foot of the eastern side of the Middle Valley in an area with low heat flow $[1,2]$. The sediments from these holes are unaltered. They are the background for the Middle Valley of the Juan de Fuca Ridge.

The sedimentary section in the "Dead Dog" hydrothermal field consists of turbidites interbedded with hemipelagic sediments. It was divided into several units [1].

Unit I - sediments is unaltered consist of clays, aleurites and quartz-plagioclase sands. Mica, amphiboles, zircon, pyrite, calcite, glauconite, opaque minerals are present in small amounts. Biogenic components consist of foraminifers, diatoms, radiolaria, nannofossils.

Units IIA, B, C, D are divided according to the level of lithification, and the degree of hydrothermal alteration and brecciation of sediments.

Unit IIA is unaltered to slightly altered sediments consist of quartz-plagioclase aleurite and aleuritic sands, the presence of chlorite, mica, hematite, pyrite, hornblende, zircon, zoisite, carbonate nodules.

Unit IIB - brecciated hemipelagic sediments and turbidites with anhydrite and carbonates and the local concentrations of sulphides $(\sim 2 \%)$. Unit IIC - lithificated hydrothermally altered sediments, quartz, plagioclase, biotite, zircon, epidote, hematite, amphibole, carbonate nodules, carbonate cement, anhydrite, disseminated pyrite.

Unit IID - silicified hydrothermally altered sediments composed of quartz, feldspars, mica, zeolite, chlorite, pyrite (5\%), as well as locally impurity of sphalerite.

Contents of macroelements in sediments were determined by the XRF method at the Geological Institute (Russian Academy of Sciences) coupled with methods of analytical chemistry for the separate determination of $\mathrm{Fe}_{2} \mathrm{O}_{3}, \mathrm{FeO}, \mathrm{CO}_{2}, \mathrm{Corg}$, and $\mathrm{H}_{2} \mathrm{O}^{-}$. Contents of microelements (REE included) were determined by the ICP-MS method with the decomposition of powdered fraction samples in an autoclave. The ICP-MS analysis was accomplished in the laboratory for Nuclear-Physical and Mass Spectral Methods of 
Analysis (Institute of Microelectronics, Technology, and High Purity Materials, Russian Academy of Sciences).

\section{Results}

Macroelements. In Hole 858B, in hydrothermally altered sediments (Units IIB and IID), almost the same change in the content of macroelements and Corg was found. (Fig. 3). The content of $\mathrm{K}$ has strong decreased in them, the content of $\mathrm{Ca}, \mathrm{Na}, \mathrm{P}, \mathrm{C}_{\text {org }}$ has decreased to a lesser extent, as well as $\mathrm{Ti}, \mathrm{Al}$. At the same time, $\mathrm{Mg}$ content increased. Mn content increased only in Unit IIB. Change the content of macronutrients and Corg. in Hole 858B in Units IIB and IID is almost the same.

In Holes $858 \mathrm{D}$ and $858 \mathrm{~F}$, changes in the content of macroelements and Corg. in Unit IID repeats the change that occurred in Unit IID in Hole 858B. The change in the content of macroelements Unit IIA (Holes 858D, F) is close to the change that is found in Unit IID. Change the content of macroelements and Corg. in Units IIA and IID occurred, as in Hole $858 \mathrm{~B}$, almost the same.

Thus, the sediments from the upflow zones of hot fluids in the modern hydrothermal system are altered almost equally in Units IIA, B, D from Holes 858B, D, F, regardless of whether the sediments belong to one or another unit, selected by the level of lithification, degree of hydrothermal alteration and brecciation of sediments.

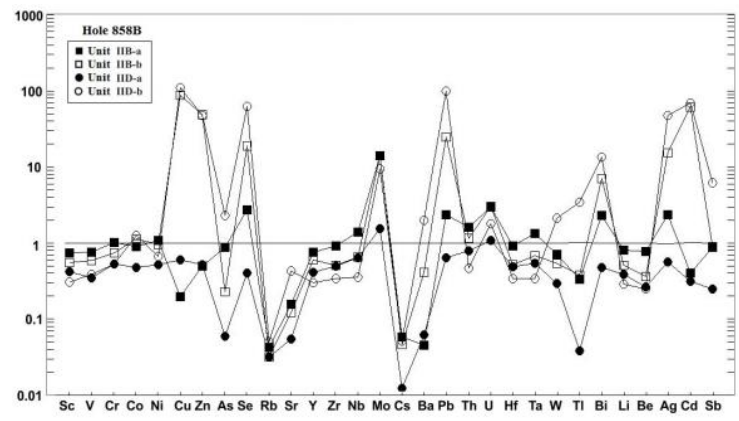

Fig. 3. Composition of the average content of macroelements in the hydrothermally altered sediments, Hole 858B, Units IIB and IID (normalized to the average content of macroelements in unaltered sediments).

Microelements. In Hole 858B there is a more complex picture of changes in the content of microelements in Units IIB and IID, than a practically identical change in macroelements in these units. Due to the difference in changes in the content of a number of microelements in Unit IIB, it is divided into Unit IIB-a (upper part of Unit IIB) and Unit IIB-b (lower part of Unit IIB). In Units IIB-a and IIB-b, the degree of change in the content of some microelements differs, while the other elements coincide.

In the lower part of Unit IIB (Unit IIB-b), the content of many microelements has changed strongly compared to their content in unaltered sediments. The contents of $\mathrm{Cu}, \mathrm{Zn}$, $\mathrm{Se}, \mathrm{Mo}, \mathrm{Pb}, \mathrm{Bi}, \mathrm{Ag}, \mathrm{Cd}$ increased. The contents of As, Rb, Sr, Zr, Nb, Cs, Ba, Ta, W, Tl, Li, $\mathrm{Be}$ in this unit decreased to different degrees. In the Unit IIB-a, there was also an increase in the content of $\mathrm{Se}, \mathrm{Pb}, \mathrm{Bi}, \mathrm{Ag}$, but it was less more slightly than in Unit IIB-b. The change in the content of $\mathrm{Cu}, \mathrm{Zn}, \mathrm{Ta}, \mathrm{Cd}$ has the opposite sign, compared with the change in the content of these elements in Unit IIB-b. At the same time, in Units IIB-a and IIB-b, a coincidence is observed in the change in the content of several microelements in intensity and in sign. This applies to Sc, V, Rb, Sr, Mo, Cs, U, W, Tl. The change in the content of $\mathrm{Ba}, \mathrm{Pb}, \mathrm{Bi}, \mathrm{Ag}$ in Unit IIB-a coincides in sign with the change in their content in Unit IIB-b. 
In Unit IID (Hole 858B), the content of microelements also varied unevenly throughout the entire thickness. Therefore, it was divided into Unit IID-a (the upper part of Unit IID) and Unit IID-b (the lower part of Unit IID). In Unit IID-A, changes in the content of microelements are close and sometimes coincide with their changes in Unit IIB-a, and changes in the content of microelements in Unit IID-b for most trace elements coincide with changes in the content of trace elements in Unit IIB-b.

In Hole $858 \mathrm{D}$ in Unit IID, there were changes in the content of microelements, mainly such as in Hole 858B, in Unit IID-b.

Unit IIA in holes drilled near hot springs was studied by us in Hole 858D. Unit IIA is located above Unit IID. In Unit IIA, there is a relatively strong increase in the content of $\mathrm{As}, \mathrm{Se}, \mathrm{Pb}, \mathrm{W}, \mathrm{Tl}, \mathrm{Ag}, \mathrm{Sb}$ and a less intense increase in the content of $\mathrm{Cr}, \mathrm{Ni}, \mathrm{Rb}, \mathrm{Zr}, \mathrm{Nb}$, Th, U, Hf, Ta. The contents of Co, Zn, Sr, Cs, Ba, Li decreased.

In general, a change in the content of many microelements, different in intensity and sign, is characteristic of sediments overlying the hydrothermally active center of spreading. The uneven distribution of microelements in Units IIB and IID resembling a layer cake probably indicates participation in the processes of changing the content of microelements in sedimentary units located in near hot springs, both ascending hydrothermal fluids and lateral hydrothermal flows.

Rare earth elements. In Hole $858 \mathrm{~B}$ in samples KB-5H and 2186, which characterize Unit IIB-a, the change in the REE content almost did not occur, except for Eu, the content of which has greatly decreased (Fig.4).

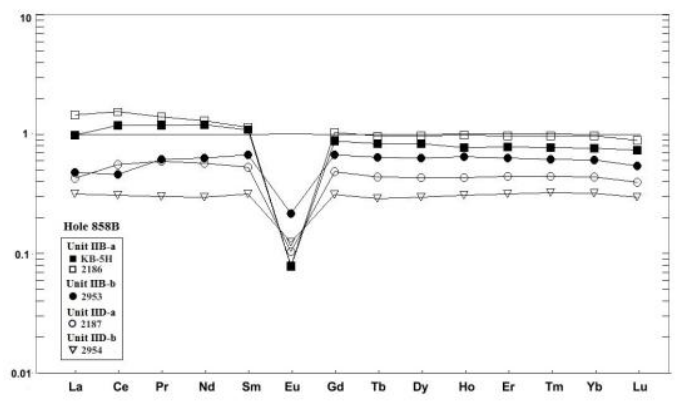

Fig. 4. Composition of the content of REE's in the hydrothermally altered sediments, Hole 858B, Units IIB, D (normalized to the average content of REE's in unaltered sediments).

In Holes IIB-b (sample 2953) and IID-a (sample 2187), an almost identical decrease in the REE content was observed, the Eu content was strongly reduced, just as in Unit IIB-a. In the lowest part of the sediment section from Hole 858B, in Unit IID-b (sample 2954), the strongest decrease in the REE content was manifested. In this unit, as in all overlying strata, the content of Eu was sharply decreased. As a result, a negative Eu anomaly is observed in all units in Hole 858B.

In Hole $858 \mathrm{D}$, in Unit IIA, which is located above Unit IID, there is no change in the REE content in the uppermost sample (ZT-60) compared to their content in the unaltered sediments (Fig. 5). In the sample KB-4H-4, which was selected below the sample ZT-60, the content of REE increased and a negative Eu anomaly appeared. In the lower part of Unit IIA (sample 2197), the REE content did not change compared with their content in unaltered sediments, with the exception of Eu, which is manifested as a negative anomaly. As in sample 2197 from Unit IIA, in Unit IID (sample 2959), the negative Eu anomaly is well pronounced. In addition, the content of heavy REE (from Dy to $\mathrm{Lu}$ ) decreased. 


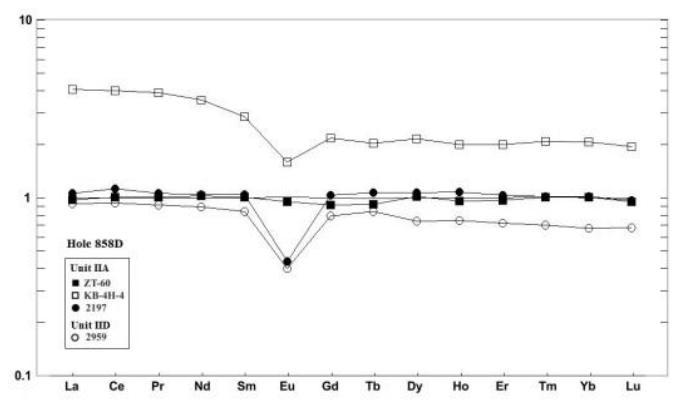

Fig. 5. Composition of the content REE's in the hydrothermally altered sediments, Hole 858D, Units IIA, D (normalized to the average content of microelements in unaltered sediments).

The change in the REE content by the type of layer pie in Unit IIA (Hole 858B), as well as microelements, indicates the effect on participation of both ascending hydrothermal fluids and lateral flows of hydrothermal solutions in alteration of chemical composition of sediments.

\section{Conclusions}

In the sediments from holes, drilled near the hot springs in the "Dead Dog" hydrothermal field in the northern part of the Middle Valley of the Juan de Fuca Ridge, the redistribution of chemical elements occurs at solution-rock interaction. In this process, an increase/decrease in the content of chemical elements in hydrothermally altered sediments mirrored the decrease/increase in their content in solution.

We used rock samples taken in the IODP Core Repository (College Station, Texas, Texas A\&M University, United States).

This work was accomplished under the State Program no. 0135-2019-0053.

\section{References}

1. E.E. Davis, M.J. Mottl, A.T. Fisher et al., Init. Repts., 139: College Station, TX (Ocean Drilling Program), 1026 (1992)

2. E.E. Davis, H. Villinger, Tectonic and thermal structure of the Middle Valley sedimented rift, northern Juan de Fuca Ridge. Init. Repts, 139: College Station, TX (Ocean Drilling Program), 9-41 (1992)

3. B. Bornhold, J.V. Firth et al., Proc. ODP, Init. Repts, 169S: College Station, TX (Ocean Drilling Program), 592 (1998) 